\title{
Literatura, História e Medicina: a FORMAÇÃO E O QUOTIDIANO PROFISSIONAIS DE ZÊNON, MÉDICO DO SÉCULO XVI, EM A OBRA em NeGro de Marguerite Yourcenar.
} Vanessa Costa e Silva Schmitt e Robert Ponge

A escritora francófona Marguerite Yourcenar (1903-1987) ascendeu à celebridade e confirmou sua excelência literária, sobretudo, com a publicação de dois romances históricos: Memórias de Adriano (1951) e A Obra em Negro (1968). É sobre o segundo título que se debruça este trabalho.

Partindo da preocupação em estudar a presença e a imagem da história e da sociedade na literatura, o presente artigo visa a analisar como é mostrada a medicina do século XVI em A Obra em Negro. O objetivo é apontar e destacar o material histórico (e, assim fazendo, avaliar sua qualidade) com o qual Marguerite Yourcenar construiu sua obra. ${ }^{1}$

Diante da amplidão do tema, ou seja, a medicina praticada nesse século de descobertas e repressão, atemo-nos aqui a dois assuntos. Inicialmente, examinamos muito brevemente a caminhada de Zênon, o protagonista, no campo da aprendizagem e do estudo da medicina: a primeira formação, a escola de medicina que frequentou, os deslocamentos que buscou a fim de aprimorar seu conhecimento técnico-científico. $\mathrm{Na}$ continuidade, evidenciamos mais detalhadamente o quotidiano de trabalho e a vida social de Zênon em Bruges, sob a identidade de Sebastiāo Theus: onde trabalhava, com quais problemas de saúde se defrontava, que tipo de tratamento aplicava em seus pacientes, com quem convivia nas esferas social e profissional. Nessa abordagem, faz-se também referência às diferentes categorias profissionais do atendimento médi-

\footnotetext{
${ }^{1}$ Este trabalho encontra seu ponto de partida em partes da dissertação de mestrado de Vanessa C. S. Schmitt; várias passagens foram reelaboradas, rescritas e amplamente aumentadas. Ver: SCHMITT, Vanessa Costa e Silva. L'Homme de l'art au XVI' siècle: la médecine dans "L'Cuvre au Noir" de Marguerite Yourcenar. Dissertação de mestrado em Literatura Francesa. Orientação: Robert Ponge. Porto Alegre: Programa de Pós-Graduação em Letras da UFRGS, 2006. Disponível em www.sabi.ufrgs.br
} 
co, corporificadas em algumas personagens de A Obra em Negro. Encerramos com o último ato operatório de Zênon.

Iniciamos este trabalho, porém, com algumas reflexões acerca de...

\section{... As relações História/Literatura em A Obra em Negro}

Diferentemente do romance de costumes à la Balzac, à la Flaubert ou à la Zola (voltado para a pintura da sociedade contemporânea do autor), o romance histórico pauta-se pela reconstituição (em algum grau) de épocas passadas. Não podendo, para tanto, recorrer às experiências de vida testemunhadas por ele próprio, pelas pessoas dos círculos que frequenta e por outros coetâneos, o autor é devedor da quantidade e qualidade do conhecimento acumulado e construído pelo trabalho de um grupo específico de pesquisadores: os historiadores. Yourcenar tinha alta consciência dessa dívida, tendo-a explicitado na "Nota da autora", que se encontra ao fim do romance. Assim, quando se refere às particularidades entre a recriação de uma personagem real, tal o imperador em Memórias de Adriano, e a construção de uma personagem "'histórica' fictícia” como Zênon, médico e filósofo do século XVI, protagonista de $A$ Obra em Negro, Yourcenar reforça que o ponto de partida é praticamente o mesmo, ou seja, a história:

$\mathrm{Na}$ verdade, as providências tomadas em ambos os casos [Adriano e Zênon] tiveram por base pontos de partida semelhantes. No primeiro deles, a romancista, para tentar representar em toda a sua amplitude a personagem tal como foi, não estudará jamais com suficiente minúcia apaixonada o dossiê de seu herói, tal qual a tradição histórica o constituiu; no segundo caso, para dar à sua personagem fictícia aquela realidade específica, condicionada pelo tempo e o lugar, sem o que o 'romance histórico' não passa de um baile de máscaras bem ou mal sucedido, não teve à sua disposição

"(YOURCENAR, Marguerite. "Nota da autora". In: A Obra em Negro. Traduzido do francês por Ivan Junqueira. Rio de Janeiro: Nova Fronteira, 1981: 319.) senão fatos e datas da vida passada, isto é, a História.”*

Embora Zênon não consista na síntese de personagens reais da época em que se ambienta o romance, Yourcenar não esconde, no entanto, as fontes de inspiração para sua composição. Para ela, "numerosos pontos de sutura vinculam o imaginário filósofo a essas autênticas personalidades que se escalonam ao longo desse mesmo século, bem como a algumas outras que viveram nos mesmos lugares, passaram por aventuras análogas ou tentaram atingir os mesmos objetivos". Segundo ela, Erasmo, Campanella, Paracelso, 
Leonardo da Vinci, Giordano Bruno, Fracastor e Bernard Palissy, entre outros, apresentam certo paralelismo, em diferentes escalas, com a figura de Zênon. Da mesma forma, Yourcenar apresenta, na sua "Nota", alguns itens bibliográficos de que se valeu para ambientar o romance e construir suas personagens, obras referentes a diversos campos do saber, tais como medicina, filosofia, história, teologia, química, alquimia e direito. A autora afirma igualmente que alguns incidentes históricos foram ligeiramente alterados "para permitir que os mesmos figurassem no quadro da presente narrativa", assim como explicita e justifica as modificações que implementou. Enfim, Yourcenar presenteia o leitor com referências e explicaçôes que denotam seu rigor histórico e científico, para que os fatos reais ou fictícios que atravessam o romance sejam compreendidos por aqueles que se interessam pela gênese e a análise de $A$ Obra em Negro.

Antecipando desde já nossa conclusão a este respeito, salientamos a importância, o primor e a excelência tanto do trabalho de pesquisa histórica desenvolvido por Yourcenar quanto do criativo aproveitamento literário que, com inteligência, sensibilidade e arte, conseguiu realizar. A contextualização histórica permeia a tal ponto A Obra em Negro que se configura a presença de algo maior do que uma simples tela de fundo histórica ou ilustração da época em que a autora faz viver seu protagonista; trata-se do próprio mundo em que age e pensa Zênon. Yourcenar retrata, de maneira impecável, diversas dimensóes da história, da sociedade e da vida durante o Renascimento: desde as disputas pela região milanesa entre o rei da França e o imperador Carlos Quinto até as reações dos trabalhadores das tradicionais tecelagens flamengas frente às inovaçôes do maquinário têxtil, passando pelo progresso da técnica e da ciência, pelos debates filosóficos e pela ebulição de conflitos religiosos, entre outros aspectos.

Antes de adentrar nas relações tecidas por Yourcenar entre medicina e literatura na obra em estudo, parece-nos necessária uma enxuta exposição da intriga central do romance: em $A$ Obra em Negro, pode-se acompanhar parte da trajetória de vida de Zênon, médico, filósofo e alquimista, quando este, após levar uma vida errante, restabelece-se em Bruges, sua cidade natal. Por ser per- 
seguido pela Santa Inquisição, o protagonista vale-se de uma falsa identidade (a do médico Sebastião Theus). Mesmo assim, acaba sofrendo um processo, que finda por sua condenação à morte. $\mathrm{Na}$ sua última expressão de liberdade, o suicídio substitui a dolorosa morte na fogueira.

\section{A formação médica de Zênon}

No século XVI, algumas categorias profissionais da arte de curar podem ser identificadas claramente: os barbeiros-cirurgiōes; os curandeiros ou empíricos; os enfermeiros; os herboristas e, obviamente, os médicos, cada qual obedecendo a uma formação particular. ${ }^{2}$

Analisaremos agora brevemente alguns aspectos relativos à iniciação e formação de Zênon, contextualizando-as naquelas próprias aos médicos de seu tempo.

\section{A primeira aprendizagem de Zênon: observação junto ao barbeiro-cirurgiáo}

Em A Obra em Negro, Zênon, ainda criança, tem a curiosidade pelas ciências aguçada pelo cônego Campanus, tio e preceptor, que se vale da vasta História natural de Plínio, o Velho, naturalista romano (23 D.C-79 D.C). Embora inicialmente destinado à vida clerical devido à sua condição de bastardo, o protagonista começa a frequentar o barbeiro-cirurgião João Myers, fato que preocupa a família do jovem flamengo por uma série de razôes: além de contrariar os planos de uma carreira promissora no clero, a profissão de médico não goza de muito prestígio na época e, sobretudo, as atividades profissionais de um barbeiro-cirurgião (prático que se ocupa de tarefas tidas por menores, como extraçôes dentárias, sangrias, amputações e remoção de cálculos renais ${ }^{3}$ ) são vistas com preconceito pela burguesia.

\footnotetext{
${ }^{2}$ Sobre as diversas categorias da arte de curar, ver: SCHMITT; PONGE. "A medicina em A Obra em Negro de Marguerite Yourcenar: as diversas profissões da arte de curar no século XVI". In: Anais do $1^{\circ}$ Fórum das Literaturas Estrangeiras Modernas do PPG em Letras da UFRGS. In: Contingentia (www.seer.ufrgs.br), vol. 3, n. 2. Porto Alegre: Setor de Alemão do Instituto de Letras da UFRGS, nov. 2008: 240-251, artigo que retoma uma subparte do capítulo 5 de Schmitt. L'Homme de l'art au XVI siècle [...]. op. cit.: 119-129.

${ }^{3}$ Procedimento chamado litotomia ou cistotomia, também conhecida como cirurgia da talha da pedra.
} 
Sendo assim, Zênon começa a cursar, com brilhantismo, a insigne Escola de Teologia de Lovaina. Entretanto, não abandona o interesse pelas ciências naturais, servindo-se das férias e dos momentos de folga para herborizar. Ainda aspirante a clérigo, vê-se menosprezado pela própria família após ter submetido um fazendeiro acometido de congestão a uma sangria, segundo as instruçōes de Myers: "O cônego Campanus deplorou tal ignomínia; Henrique-Justo, ${ }^{4}$ vindo em socorro deste, lastimou em alto e bom som os ducados que investira no custeio dos estudos do sobrinho, caso fosse terminar entre um escalpo e um bacinete. ${ }^{5}$

Em sigilo, Zênon examina com o barbeiro as possibilidades de estudo da medicina.

\section{$O$ ensino da medicina nas universidades europeias na época de Zênon}

Para tornar-se médico no século XVI, é preciso seguir um curso superior. Aqueles atraídos pela prática da arte ou naturalmente conduzidos a ela por uma tradição familiar ${ }^{6}$ podem escolher uma das célebres faculdades de medicina europeias (Montpellier e Paris, na França; Bolonha e Pádua, na Itália; Lovaina, em Flandres). Myers sugere a Faculdade de Paris, onde ele mesmo havia estudado, sem nunca ter obtido o diploma; porém o espírito audacioso do aprendiz anseia por viagens a terras longínguas, que não são explicitadas. Em A Obra em Negro, toma-se conhecimento, posteriormente, de que Zênon aplicou-se durante um período à aprendizagem de investigaçôes alquímicas em Gand (Flandres) e León (Espanha) e que, na sequência, seguiu seus estudos médicos e diplomou-se na Universidade de Montpellier.

Nessa época, é mais filosófico do que científico o curso de medicina oferecido pela maioria das universidades. Nas faculdades um pouco mais liberais, como Bolonha e Pádua, realizam-se, uma ou duas vezes por ano, sessões públicas de dissecção, que atraem, além

\footnotetext{
${ }^{4}$ Henrique-Justo Ligre é um rico mercador e banqueiro, tio que abriga e sustenta Zênon desde que a mãe deste, Hilzonda, casou-se e mudou-se de cidade.

${ }^{5}$ YOURCENAR, Marguerite. A Obra em Negro. Traduzido do francês por Ivan Junqueira. Rio de Janeiro: Nova Fronteira, 1981: 39. As referências das demais citaçôes de A Obra em Negro serão dadas diretamente no texto, entre parênteses, após a citação, precedidas da abreviação ON. Também foi utilizada, para fins de cotejamento, uma edição na língua original, o francês: YOURCENAR, Marguerite. L'Euvre au Noir. (1968). Paris: Gallimard, coll. "Folio", 1991.

${ }^{6} \mathrm{~A}$ carreira médica é, sobretudo, seguida pelos filhos da pequena burguesia.
} 
*(VONS, Jacqueline. L'Anatomie au XVle siècle. http:// www.bium.univ-paris5.fr/ histmed/medica/anatomie. $\mathrm{htm})$

'(SAUNDERS, J., O'MALLEY, C. "Esboço biográfico". In: Vesalius, Andreas. De Humani Corporis Fabrica. Epitome. Tabulae Sex. São Paulo: Ateliê Editorial; Imprensa Oficial do Estado; Campinas: Editora Unicamp, 2002: 15-42.)

"(Yourcenar. "Nota da autora". In: op. cit.: 325 .)

•(ON: 105.)

* (LEFRANC, Abel. La Vie quotidienne au temps de la Renaissance. Paris: Hachette, 1938: 200-201.)

( $(\mathrm{ON}: 57$. de estudantes, alguns artistas e o público em geral. A dissecção é feita em cadáveres de condenados, o que justifica a escassez de disseç̧ões em mulheres e em crianças. Enquanto o professor, no púlpito, lê um texto clássico, geralmente de Galeno (médico de Pérgamo, aprox. 131-201), ${ }^{7}$ um demonstrador disseca o cadáver, ao qual os estudantes não tem nenhum acesso. * Tal situação só começará a ser modificada por André Vesálio (Andreas Vesalius, 15141564), professor e anatomista da Universidade de Pádua. Ele mesmo disseca os cadáveres, explicando aos estudantes todo o procedimento, além de ser o primeiro a elaborar pranchas anatômicas fidedignas e didáticas. ${ }^{* 8}$

Em A Obra em Negro, Yourcenar faz Zênon ser contemporâneo do professor Guillaume Rondelet (1507-1566), um dos grandes anatomistas de Montpellier, célebre por certos episódios que abalam a mentalidade da época (como o estudo, em aula, da placenta única partilhada por seus filhos gêmeos). Conforme Yourcenar, Rondelet, assim como algumas outras personagens que atravessam o livro, é tomado tal qual "à história ou às crônicas locais". Com efeito, ela transforma o protagonista em testemunha de um dos eventos reais que escandalizam a cidade: o professor faz dissecar diante de si o cadáver do próprio filho. Zênon louva a ousadia do anatomista, considerando-o um dos poucos "cérebros intrépidos" que podem ser encontrados no corpo docente da universidade.

Sessões públicas à parte, alunos e médicos dedicam-se a dissecções clandestinas, valendo-se, em geral, de cadáveres recém-sepultados que são furtivamente desenterrados. ' Quanto à Zênon, os boatos sugerem que, algum tempo após sua partida de Bruges, teria sido visto na rua da Carvoaria, em Paris, "onde os estudantes dissecavam cadáveres em segredo”, todavia não há confirmação por parte do flamengo de que tenha seguido estudos médicos lícitos (ou não) na capital.

\footnotetext{
${ }^{7}$ Para maiores informaçôes sobre Galeno e sua influência inabalável na medicina até o séc. XVI, ver: BOORSTIN, Daniel. Les Découvreurs. Traduit de l'anglais par Jacques Bacalu, Jérôme Bodin et Béatrice Vierne. Paris: Robert Laffont, coll. "Bouquins", 1988: 331-338; BRUNET, Pierre. "La Science dans l'Antiquité et le Moyen Âge”. In: DAUMAS, Maurice (dir.). Histoire de la science. Paris: Gallimard, "Encyclopédie de la Pléiade”, 1957: 193-366, em particular as páginas 281-287)

${ }^{8}$ Para maiores informaçôes sobre Vesálio e a inovação que representou em sua época, consultar também DRĖZE, Ch. "André Vésale et De Humani Corporis Fabrica Libri Septem”. Louvain Med. n. 117, 1998: 272-278; e BOORSTIN, Daniel. Les Découvreurs. op. cit.: 338-348.
} 
O deslocamento constante dos estudantes de medicina e dos médicos é um costume singular nessa época de intolerância religiosa e de pouca disseminação dos saberes. Assim, o prestígio individual de alguns professores, também viajantes, faz com que um número significativo de discípulos desloque-se atrás dos mestres. De acordo com Delaunay, "[o médico do século XVI] peregrina afim de se instruir, desloca-se para viver, muda-se para instruir-se novamente, e ver-se-á até mesmo forçado a exilar-se para poder orar à vontade", " definição que parece resumir a trajetória de vida da personagem Zênon; não por acaso a primeira parte do romance intitula-se a "A vida errante".

\section{A formação continuada de Zênon durante sua vida errante}

Procedendo-se a uma breve análise de tempo e espaço em $A$ Obra em Negro, observa-se que a errância corresponde a 33 anos da existência de Zênon, ou seja, de 1530 à $1563 .{ }^{9}$

Do ponto de vista espacial, pode-se constatar que os primeiros vinte anos de Zênon, entre 1510 e 1530, são bem pouco nômades, restritos a Flandres: inicialmente, no ambiente urbano de Bruges (onde é criado), com veraneios em alguma propriedade rural de Henrique-Justo Ligre; posteriormente, cursa a Escola de Teologia de Lovaina e segue para Gand, cidades respectivamente localizadas a 120 e 40 quilômetros ao leste-sudeste de Bruges.

A partir de 1530, começa verdadeiramente a vida errante: Zênon viaja muito, conhecendo diversos países, cidades e vilarejos; lugares que percorre seja como estudante, seja exercendo a medicina, seja em busca de conhecimentos diversos, de aperfeiçoamento técnico-científico ou em fuga, já que vem sendo perseguido pela Santa Inquisição devido às suas Proteorias, que são escritos filosóficos: León, Montpellier (onde segue os estudos de medicina), Pont-Saint-Esprit, Avignon, Argel (e regiōes barbarescas), Pera (Constantinopla), ${ }^{10}$ Lyon, Buda, Bolonha, Colônia (onde estu-

\footnotetext{
${ }^{9}$ Os dados relativos à duração, à datação e à localização espacial são tirados do romance, da "Nota da autora" e dos "Carnets de notes de L'Euvre au Noir" (disponível na edição em língua francesa anteriormente citada, p. 445-486). Foi consultada também a utilíssima cronologia estabelecida por Daniel RégnierRoux en seu artigo: "Les Cloisons du temps semblaient avoir éclaté: réflexions sur la chronologie dans L'Euvre au Noir de Marguerite Yourcenar". Bulletin de la S.I.E.Y., n. 17, 1996: 21-40.

${ }^{10}$ Segundo Ivan Junqueira, tradutor para o português da edição brasileira utilizada, em nota à página 106, trata-se do antigo nome do bairro de Bey glu, em Istambul.
}

(Delaunay, Paul. "L'Évolution médicale du $\mathrm{XVI}^{\mathrm{e}}$ au XXe siècle". Bulletin de la Société française d'histoire de la médecine, $\mathrm{n}$. 22, 1928: 17. Traduzido por nós, Schmitt/Ponge) 
da os efeitos da peste), Basileia, Innsbruck, Würzburg, Salzburgo, Turíngia, Lübeck, Upsal, Estocolmo, Vadstena, Frösö (onde toma conhecimento de técnicas curativas herdadas de feiticeiras da Lapônia), Polônia (onde se engaja, na qualidade de cirurgião, nos exércitos do rei Sigismundo), Paris, entre outras, e não exatamente nesta ordem.

Paris, ano de 1563. Vendo o círculo da perseguição fechar-se em torno de si, Zênon opta pelo retorno incógnito à terra natal, Bruges, valendo-se da falsa identidade de Sebastião Theus. Em Senlis, embarca na carruagem do prior dos franciscanos de Bruges rumo à sua "vida imóvel", cujo epílogo será a morte.

O quotidiano de vida e de trabalho de Zênon (sob o
criptônimo de Sebastião Theus) em Bruges

Trata-se do quotidiano médico e social de Zênon/Theus em Bruges, após um longo período de errância. Procura-se, nesta parte, mostrar primeiramente alguns casos clínicos e cirúrgicos com os quais ele se defronta durante a prolongada permanência em Bruges, assim como quais terapêuticas costuma empregar em tais situações. Após este levantamento relativo ao seu exercício médico, segue-se a apresentação do dispensário do asilo de São Cosme, principal local de trabalho do protagonista. Na sequência, são apresentados alguns elementos referentes à prática da herborização e aspectos da vida social do médico flamengo que estão intimamente ligados à sua postura existencial.

Os pacientes e os casos clínicos e cirúrgicos de Sebastião Theus em Bruges

Quando Zênon volta a Bruges, na pele do doutor Sebastiāo Theus, encarrega-se inicialmente da clientela do velho João Myers, seu antigo mentor. Após a morte deste, ele herda seus bens. Além de cuidar dos antigos pacientes do barbeiro-cirurgião, cria um dispensário (espécie de enfermaria) vinculado ao asilo de São Cosme (instituição administrada pelos monges franciscanos), a fim de ali atender os pobres da região e os camponeses que afluem à cidade em dias de mercado.

Depara-se com diversas situações clínicas e cirúrgicas no seu dia a dia, tanto no dispensário quanto fora dele; algumas são relatadas mais detalhadamente no romance, outras, muito brevemen- 
te. Assim, sabe-se que atende uma paciente que deseja um remédio para sua dor ciática, cuja terapêutica é a aplicação de um "poderoso revulsivo"; ${ }^{11}$ que extirpa um tumor benigno; que recebe, regularmente, a visita de uma prostituta tísica em busca de medicamentos para tosse. ${ }^{*}$ Igualmente procura tratar uma menina com lúpus; no que diz respeito a esta doença então incompreendida, Theus percebe que a luz aumenta os danos causados pela doença, sugerindo que a garota ande sempre coberta por um véu negro. ${ }^{*}$ Toma-se conhecimento, também, de uma senhora idosa que frequenta semanalmente a enfermaria a fim de limpar suas feridas varicosas, ${ }^{*}$ personagem anônima diluída na multidão de pacientes desfavorecidos que o médico atende diariamente. Contudo, dois casos merecem destaque no seu quotidiano de atendimento profissional, um deles cirúrgico, a redução de uma fratura exposta; outro, clínico, o diagnóstico e o acompanhamento de um tumor na garganta.

Numa noite de verão, após o encerramento de suas atividades no dispensário, Theus é chamado a atender um jovem acidentado, cuja perna está fraturada. Ao examinar a fratura exposta do paciente, o médico constata que, por prudência, a perna deve ser amputada. No entanto, condoído, decide reduzir a fratura, procedimento inusual na época devido à precariedade das técnicas cirúrgicas. Após abrir a ferida com a lâmina, o cirurgião busca com as próprias mãos remover fragmentos ósseos, irrigando a superfície com vinho forte antes de bandar e imobilizar o membro. Deixa o local bastante incerto do resultado dessa conduta incomum; afinal, o paciente encontra-se extremamente debilitado. $\mathrm{O}$ médico retorna diariamente a fim de irrigar a lesão com vinagre, na tentativa de eliminar o pus e outras secreções, procedendo, posteriormente, à unção com água de rosas (que acredita reduzir tanto o ressecamento quanto a inflamação das bordas da ferida). No décimo dia, aproximadamente, constata a formação de um abscesso e a elevação da febre, a qual nunca havia cessado. Vale-se de uma dieta severa, tentando recuperar as forças do doente. No entanto, o quadro se agrava: "Certa noite, os músculos se contraíram com tamanha violência que a perna rompeu a tala". Nessa hora, culpa-se por sua comiseração durante a operação, admitindo que, "por uma condenável piedade, não apertara o bastante as duas ripas da tala; seria

\footnotetext{
${ }^{11}$ Revulsivo: "medicamento específico com o fim de fazer cessar, mediante uma irritação local (revulsão), um estado congestivo ou inflamatório existente em outra parte do corpo" (Dicionário Houaiss Eletrônico).
} 
de novo preciso reajustar os ossos e reduzir a fratura". Dessa vez, para que o paciente suporte melhor a intervenção, possibilitando assim um eventual resultado satisfatório, o médico o envolve num vapor de ópio. Ao final de sete dias, o abscesso encontra-se drenado, assim como desaparece a febre depois de abundantes suores. Seis semanas mais tarde, o convalescente movimenta-se bem com a ajuda de uma bengala, mas as aderências da cicatriz o fazem ainda sofrer. Cerca de seis meses depois, fica-se sabendo que o jovem está em plena forma.

Quanto ao principal caso clínico cujo desenlace pode ser acompanhado em A Obra em Negro, trata-se da doença crônica apresentada por João Luís de Berlaimont, prior dos franciscanos em Bruges, por quem o médico nutre uma grande amizade. Numa de suas longas conversas habituais, Theus percebe que o prior tem a face banhada em suor, o que lhe parece, inicialmente, sintomático de um estado de fraqueza; no entanto, outros sinais não tardam a aparecer. A cada visita, o profissional identifica marcas de um mal indefinível que suga as forças do paciente. Como primeira prescrição, indica o consumo de restaurativos misturados ao vinho. Com o passar do tempo, crises de tosse persistentes chamam a atenção; somadas ao mau aspecto da fácies e à consumpção crescente, fazem com que o médico sugira um exame da garganta com a ajuda de um espéculo especial. Chegado o inverno, o prior renuncia espontaneamente a pregar os sermões do Advento devido à rouquidão crônica. Theus consegue de seu paciente que repouse no leito, após o jantar, por uma hora a fim de poupar suas forças. Apesar do repouso e das gotas adstringentes receitadas, a doença continua a avançar. O médico está consciente de sua impotência perante o sombrio diagnóstico que se desenha: um pólipo na garganta (capaz de justificar a rouquidão, a tosse, a dificuldade em respirar e engolir, já que a ausência de febre descarta a possibilidade de tísica). ${ }^{12}$ Visando a certificar-se da afecção, ele consulta as pranchas anatômicas de um tratado publicado por Vesálio cerca de vinte anos antes, obra que herdou de Myers: ${ }^{13}$

Colocando o in-fólio sob a luz da lamparina, Zênon procurou a lâmina em que se reproduzia um corte de esôfago e de laringe com

\footnotetext{
${ }^{12}$ Tísica: antiga denominação da tuberculose pulmonar.

${ }^{13}$ Trata-se provavelmente do célebre tratado De Humani Corporis Fabrica (1543), posto que parece ser o único trabalho de Vesálio em que constam pranchas anatômicas representando a regiáo da laringe.
} 
a artéria traqueal: o desenho lhe pareceu um dos mais toscos do grande anatomista, mas Zênon não ignorava que Vesálio, como ele próprio, deveria ter sido obrigado amiúde a trabalhar muito depressa sobre exemplares de carne já em putrefação. De repente, seu dedo identificou o lugar em que supunha desenvolver-se, na garganta do prior, aquele pólipo que, mais dia menos dia, sufocaria por completo o doente. Tivera na Alemanha a oportunidade de dissecar o corpo de um vagabundo que morrera vítima do mesmo mal; essa lembrança e o exame feito com a ajuda do speculum oris induziam-no a diagnosticar, com base nos obscuros sintomas da doença do prior, a ação nefasta de uma parcela de carne que devorava aos poucos as estruturas vizinhas.*

A patologia sendo inacessível ao bisturi e ao cautério, nada resta a fazer senão tentar restaurar a energia do paciente com a ajuda de um regime prudente, evitando a qualquer custo as sangrias e purgaçôes usualmente recomendadas por práticos e médicos, terapêuticas que, em geral, são responsáveis por "esgotar barbaramente a substância humana”. Quando o estado físico do prior se agrava, solicita a uma paciente e amiga que prepare alimentos leves como caldos coados e xaropes; no entanto, João Luís de Berlaimont morre lentamente. ${ }^{*}$ Próximo do fim, o prior recusa a poção calmante à base de opiáceos que se lhe administra todas as noites, a qual o médico substitui por longas massagens nas pernas e nos pés. Numa alvorada, na companhia deste e recitando de maneira quase inaudível a Ave-Maria, o franciscano dá adeus à sua existência terrena.

\section{O dispensário do asilo de São Cosme}

É no dispensário do asilo de São Cosme que Theus passa grande parte do seu dia e atende um vasto número de pessoas. Baseado nos registros hipocráticos, mantém um diário concernente aos pacientes por ele ali atendidos, no qual descreve os casos clínicos com seus sintomas, sua evolução diária e seu desfecho. Às vezes, durante a manhã, dedica-se a atualizar estas notas no seu local de trabalho.

No estabelecimento, recebe a ajuda de dois monges que se tornam auxiliares enfermeiros. O primeiro monge encarregado do cuidado aos doentes é dispensado por roubar medicamentos para depois vendê-los na rua, sendo substituído por Cipriano, que se soma ao frei Lucas: Sebastião Theus "já podia agora fiar-se em dois monges que haviam afinal aprendido pelo menos os rudimentos da arte de tratar de alguém".* 
Frei Lucas torna-se praticamente o responsável pela enfermaria enquanto Theus dedica-se integralmente ao prior dos franciscanos: "Frei Lucas era homem sereno, cônscio de seus deveres e cujo espírito não ia muito além do que lhe exigia a urgência do trabalho a ser feito".

Frei Cipriano possui um sorriso agradável e está sempre disponível para com os pobres que frequentam o local. Apesar da sua tolice, tem seus talentos de enfermeiro reconhecidos pelo doutor: “[...] o rapaz indolente possuía uma destreza invulgar para aplicar um emplastro ou enrolar uma bandagem; nenhuma chaga ou ferida, nenhum abscesso o assustavam ou nauseavam". Todavia é preciso controlá-lo, pois crê em superstições que o fazem aplicar imagens baratas de santos milagreiros sobre as feridas dos pacientes. Uma das funçôes de Cipriano é ajudar o médico a limpar os instrumentos após o horário de fechamento do estabelecimento.

A enfermaria dispõe de uma estufa à moda alemã desenvolvida e construída pelo próprio médico, que acredita ser útil no tratamento dos reumáticos e sifilíticos. Embora faça algum uso do mecanismo, ele constata, posteriormente, que utilizou pouco o banho, a água e o vapor porque os doentes são "amiúde avessos a essas preocupações".

No dispensário, dedica-se aos pobres que ali vêm buscar alívio para seus males. Mitigar as misérias dos desfavorecidos pelo exercício da arte médica resume seu quotidiano. $\mathrm{O}$ fato de permanecer imóvel em Bruges, restrito aos muros do hospital, leva-o a fazer reflexões sobre seu trabalho:

Sabia que seu instrumental de médico compunha-se em partes iguais de destreza manual e de fórmulas empíricas, também elas coadjuvadas por achados experimentais que, por sua vez, conduziam a conclusōes teóricas sempre provisórias: um grama de observação lógica valia nessas matérias mais do que uma tonelada de sonhos. $\mathrm{E}$, todavia, após tantos anos dedicados à investigação anatômica da máquina humana, desistira de aventurar-se mais audaciosamente à exploração do reino limitado por fronteiras de pele, no qual nos julgamos príncipes, mas onde somos apenas prisioneiros."*

Prisioneiro cuja sentença revogável foi imposta por ele mesmo, Zênon/Theus encontra-se cada vez mais imóvel. Mesmo suas jornadas de herborização ocorrem mais raramente. 
Cabe salientar a importância da herborização numa época em que ainda não se conhecem outras drogas além daquelas encontradas na natureza. Além de ser praticada por boticários, a herborização é uma atividade usual para alguns médicos que se interessam pelas ciências naturais e pela botânica, como é o caso do protagonista de A Obra em Negro.

Desde a juventude, ele mantém o hábito de realizar saídas de campo, em geral noturnas, com essa finalidade, que não se pode ignorar íntima do estudo dos minerais e das espécies animais. Em Dranoutre, nos arredores da região em que estava situada a residência estival de Henrique-Justo, o jovem Zênon saía pelos campos, ao alvorecer, "em busca não se sabe de que sabedoria diretamente advinda das coisas", observando as pedras, a terra e os insetos, perscrutando assim os mistérios da natureza. Em outra ocasião, levando consigo provisões para vários dias, aventurou-se na floresta de Houthuist, cujos bosques "constituíam o que restara da aglomeração de grandes árvores da época pagã”:

A cabeça erguida, descortinando lá embaixo o verde e espesso tapete de agulhas, ele voltava às especulaçôes alquímicas que iniciara na escola, ou apesar dela; redescobria então, em cada uma dessas pirâmides vegetais, o hieróglifo hermético das forças ascendentes, o signo do ar, que banha e nutre os belos seres silvestres, e o do fogo, cuja virtualidade eles trazem dentro de si, mas que um dia poderá destruí-los. Entretanto, tais ascensōes somente o eram por haver uma queda: sob seus pés, o povo cego e peregrino das raízes imitava nas trevas a infinita divisão das vergônteas solares do céu, orientando-se cautelosamente para não se sabe que nadir. Aqui e ali, uma folha precocemente amarelecida denunciava sob o verde a presença dos metais de que ela formara sua substância e cuja transmutação ela operava."”

*(ON: 38-39)

Em Montpellier, na qualidade de estudante de medicina, herborizava com François Rondelet, este "irmão"* perdido tão jovem, filho do célebre professor. Mais tarde, já homem maduro e em fuga, dirigiu-se à Suécia devido à "curiosidade por novas plantas e novos climas".

Em Bruges, sob o criptônimo de Sebastião Theus, ele não perde o interesse pela botânica durante seu período de imobilidade. Numa alvorada, sai para herborizar em direção à orla das dunas, munido de uma lupa que mandara confeccionar por um oculista 
local. Com ela, examina "de perto as radículas e as favas das plantas recolhidas". Entretanto, o decréscimo na frequência de expediçôes de herborização acompanha o processo de retraimento que se opera em sua vida:

Suas peregrinações, agora muito menos frequentes, em busca de espécies botânicas, iam e vinham pelos mesmos campos cultivados e os mesmos caminhos à beira dos mesmos canais, os mesmos bosquezinhos e as fímbrias das mesmas dunas, e ele sorria, não sem amargura, dessas idas e vindas de inseto que circula incompreensivelmente sobre um palmo de terra.

\section{A vida social de Sebastião Theus}

Embora fundamentalmente centrado no trabalho como médico, seu quotidiano não se restringe à prática da arte de curar. Homem solitário, sem laços familiares, seu dia a dia compreende uma discreta vida social, permeada por momentos de solidão propícios a profundas reflexões.

Assim que chegou à cidade, retomou sua amizade com João Myers. Os dois mantêm à mesa longas conversas sobre o passado, a identidade por ele adotada e a medicina. Todas as noites, durante o jantar, o velho barbeiro pergunta-lhe sobre os pacientes que visitou, aproveitando a ocasião para narrar anedotas cômicas ou trágicas envolvendo os habitantes locais.

Theus passa a atender os poucos pacientes de que ainda se ocupava o barbeiro, uma clientela inexpressiva que não chega a atrair a inveja dos confrades. Com estes, encontra-se raramente, a troca de ideias limitando-se a alguma opinião clínica ou a comentários sobre o vento, a chuva ou algum incidente local. Considerando-se que as disputas no meio profissional costumam acontecer reiteradamente, podendo adquirir contornos violentos, o incógnito protagonista cerca-se de todo cuidado a fim de evitar quaisquer manifestaçôes que possam gerar desagrado, causar polêmica, suscitar inveja ou levantar suspeitas ao seu respeito. ${ }^{14}$ Mantendo a discrição, as conversas com os pacientes restringem-se a eles mesmos, alguns se ofendendo quando ele decide cobrar antigos honorários já esquecidos por Myers.

\footnotetext{
${ }^{14}$ Para maiores informações sobre as disputas profissionais no meio médico no século XVI e os dissabores delas advindos durante a vida errante de Zênon, ver: SCHMITT; PONGE. Artigo citado. Contingentia. op. cit.: 247-249.
} 
Habitualmente volta tarde para a casa de Myers, onde está hospedado, situada no Velho Cais do Bosque. À sala superaquecida do antigo mentor, ele prefere "o ar úmido das ruas e as longas caminhadas para além das muralhas da cidade, junto à orla dos campos cinzentos".*

Após a morte de Myers, vive sozinho num pequeno cômodo do andar superior do asilo de São Cosme. Dedica-se quase integralmente aos pacientes do dispensário e a alguns outros de quem ainda trata, atribuições pouco prestigiosas que parecem incapazes de despertar a cobiça de seus pares. Algumas vezes faz suas refeições numa hospedaria próxima, sentando-se só. Um de seus poucos amigos é o organista da igreja de São Donato, cuja esposa foi operada por ele. Seguidamente é convidado a jantar na residência do casal. Contudo, impóe-se certo isolamento que só costuma ser rompido pela prática profissional junto aos desamparados e os cuidados médicos dispensados ao prior.

Pela rotina de cuidados àqueles cativos pelas doenças, aos desvalidos, o médico flamengo renuncia às glórias. De acordo com o comentário de Yourcenar em entrevista radiofônica, o devotamento na prática da arte aos pobres corresponde à entrada de Zênon no que ela chama de a obra em branco:

[Zênon] disse a si mesmo que não ultrapassaria a obra em negro, a mais difícil de todas, porque o mais difícil é romper com nossos conceitos e separar-nos de nossas ilusões e que já era um triunfo suficiente para uma vida. Mas na época em que diz isto, ele já está nesse período de purificação e de serviço que constitui a obra em branco. Com efeito, ele renunciou a todas as ambiçôes humanas; ele pratica conscienciosamente seu ofício de médico dos pobres. Ele que se lançava impetuosamente em todo tipo de empreitadas, considerando bem pouco as consequências destas sobre outrem, pensa primeiramente nos outros.

O médico tem consciência da modificação causada nele pelo exercício da arte de curar numa humilde enfermaria:

As tarefas do dispensário não o fatigavam: sua mão e sua destreza jamais se revelaram tão firmes. Os indigentes andrajosos que esperavam pacientemente cada manhã a abertura do asilo eram tratados com tanta arte quanto o foram outrora as pessoas importantes do lugar. A total ausência de ambição ou de receio permitia-lhe aplicar mais livremente seus métodos, e quase sempre com bons resultados: essa aplicação integral excluía a piedade."

No entanto, a exclusão da comiseração na prática médica não significa ausência de emoção e de devotamento. Destacam-se em
$\cdot(\mathrm{ON}: 146$.

- (YOURCENAR in ROSBO, Patrick de. Entretiens radiophoniques avec Marguerite Yourcenar. Paris: Mercure de France, 1972: 127. Traduzido por nós, Schmitt/Ponge)

$\cdot(\mathrm{ON}: 171$. 
sua vida os momentos passados junto a João Luís de Berlaimont na humilde cela do convento franciscano, onde costumam encontrar-se "para além das contradiçôes". "Homem piedoso, culto e que havia sido chefe de família antes de abraçar o sacerdócio, Berlaimont não disfarça o espanto diante de um mundo cada vez mais incompreensível. Ele e o médico discutem filosofia, teologia e política, ambos manifestando mutuamente descrenças, desesperanças e temores, buscando no outro o consolo de uma amizade sincera. Nesta relação, religião e medicina, fé e ateísmo diluem-se na expressão genuína do amor desinteressado entre dois espíritos livres.

Envolvido involuntariamente como confidente em um caso perigoso de heresia (alguns dos jovens monges franciscanos têm mantido, rotineiramente, relações sexuais com uma garota no âmbito de uma seita chamada os anjos; ciente dos perigos que podem decorrer de tal prática, Theus tenta, sem sucesso, dissuadi-los), o médico passa a estar em risco. Quase sem notar a passagem do tempo, ele está em Bruges há seis anos e apenas sua amizade pelo prior o mantém no convento.

Inevitável, a morte do franciscano fecha um período de dedicação quase exclusiva ao doente. De agora em diante, nada retém Zênon/Theus em Bruges, a liberdade se lhe reapresenta: ele decide partir.

\section{O derradeiro ato operatório de Zênon}

Porém sua fuga não ocorre: frente às dificuldades encontradas na tentativa de partir para a Inglaterra, Zênon retoma o caminho de Bruges. Especula-se que o asilo de São Cosme fechará suas portas e que o doutor deixará a cidade a fim de viver em Lübeck, na Alemanha, onde já havia vivido antes. No entanto, o caso dos anjos é descoberto, e o nome do médico, citado. Ao ser preso, entrega-se sem nenhuma resistência e, para estupefação geral, revela sua verdadeira identidade: Zênon Ligre. Começa a terceira e última parte do romance: "a prisão".*

Além da acusação, logo declarada sem fundamento pelos inquisidores, de ter participado do caso dos anjos enquanto Sebastião Theus, Zênon é inculpado por suas Proteorias e por outros escritos em que explicita seu pensamento filosófico. Ao fim do processo conduzido pela Santa Inquisição, o qual enfrenta corajosamente, revelando tenacidade e vigor intelectual, é condenado à morte 
na fogueira pelos crimes de ateísmo e de impiedade. Seu tio, o velho cônego Campanus, que acompanhou todo o auto de acusação de perto, tenta convencê-lo a retratar-se para que possa, mediante intervenção da autoridade eclesiástica, livrar-se da pena capital. Entretanto, Zênon crê na supremacia do livre pensamento e recusa a oferta do clérigo, a quem resta a esperança de que uma noite de reflexão possa fazer o médico mudar de ideia.

Tão logo o cônego vai embora, ele começa a travar uma dolorosa batalha interior sobre o que fazer: pôr fim espontaneamente à própria vida ou deixar-se queimar vivo no dia seguinte?

Decisão tomada, Zênon vai aliviar seu próprio mal, e é sobre ele mesmo que praticará o procedimento mais difícil de sua trajetória médica:

Rapidamente, com a destreza de cirurgião-barbeiro graças à qual sempre fizera nome em meio às virtudes mais louvadas e mais incertas do médico, dobrou-se ao meio, erguendo ligeiramente os joelhos, e seccionou a veia tibial, na face externa do pé esquerdo, num dos pontos habituais da sangria. Depois, mais depressa, já na posição anterior, e de novo apoiado no travesseiro, apressando-se para prevenir uma síncope sempre possível, tateou e cortou à altura do pulso a artéria radial. A breve dor superficial causada pela pele rasgada mal foi percebida. As fontes jorraram; o sangue esguichou impetuosamente como sempre o faz, ansioso, dir-se-ia, por escapar aos obscuros labirintos em que circula enclausurado."

Enquanto seu corpo, paradoxalmente máquina frágil e vigorosa que lhe fora dotada pela natureza, encaminha-se ao fim, seu raciocínio continua ativo. Analisa fisiologicamente cada etapa de sua morte iminente, reelaborando o pensamento médico-filosófico e confirmando o que aprendera tanto na teoria quanto no exercício da profissão sobre as reações que pode sofrer um organismo que se extingue:

Relanceou o olhar sobre o cobertor já negro de sangue. Compreendia agora o filósofo por que uma noção grosseira fizera daquele líquido a própria alma, pois que a alma e o sangue escapavam juntos. Aqueles antigos erros continham uma verdade singela. Imaginou, com o equivalente a um sorriso, que a ocasião era bela para concluir suas velhas experiências sobre a sístole e a diástole do coração [...]. Seu coração batia acelerado; uma violenta e desordenada atividade reinava em seu corpo como num país em ruínas [...]. Tinha sede, mas nenhum meio de saciar esta sede [...]. Mas a sede cessaria logo [...]. O sangue da veia tibial só fluía agora por golfadas; penosamente, 
como quem ergue um imenso peso, conseguiu mover o pé para deixá-lo pender fora do leito. A mão direita, que ainda continuava a apertar a lâmina, ficara levemente ferida, mas ele já não sentia o talho. Os dedos se agitavam sobre o peito, procurando vagamente desabotoar o colarinho do gibão; esforçou-se em vão por reprimir essa inútil agitação, mas as crispaçôes e a angústia eram bom sinal. Um calafrio glacial o trespassou como no limiar de uma náusea: era exatamente assim.

Sabe-se assim que, mesmo no cruzamento do limiar que separa a vida do fenecimento, Zênon mantém a rigorosa percepção médica que sempre o caracterizou, morrendo fiel ao seu ideal de liberdade.

\section{Vanessa Costa e Silva Schmitt}

Cirurgiā-dentistagraduada pela FaculdadedeOdontologia da UFRGS; professora de francês, mestre em Literaturas Francófonas pela UFRGS, doutoranda em Estudos de Literatura na mesma instituição. Vanessa Schmitt agradece o apoio da Capes para o doutorado em curso. Endereço para correspondência: Av. Mariland, 507/602 Porto Alegre, RS. CEP: 90 440-191

E-mail: vanessa.schmitt@ufrgs.br

\section{Robert Ponge}

Doutor em Letras (USP), professor titular do Instituto de Letras da Universidade Federal do Rio Grande do Sul (UFRGS), onde leciona tradução e literaturas francófonas; pesquisador das relações Literatura/História, bem como das vanguardas literárias e artísticas, sobretudo do surrealismo. E-mail: r.ponge@ufrgs.br

Palavras-chave: Literatura e História; Literatura e Medicina; século XVl; Yourcenar (Marguerite); A Obra em Negro.

\section{Resumo}

Partindo da preocupação em estudar a presença e a imagem da história e da sociedade na literatura, este trabalho tem por objetivo analisar como é mostrada a medicina do século XVI em A Obra em Negro (1968), romance da escritora francófona Marguerite Yourcenar, cujo protagonista é o médico Zênon. Após algumas reflexões sobre as relaçōes entre literatura e história, bem como uma brevíssima exposição da intriga de $A$ Obra em Negro, atemo-nos aqui, diante da amplidão do tema, a examinar duas questôes: a formação médica de Zênon; seu quotidiano de vida e profissional na cidade de Bruges. 


\section{Abstract}

This paper, which belongs to the field of studies on the presence and image of history and society in literature, aims to analyze how sixteenth century medicine is shown in L'Euvre au Noir (1968), Marguerite Yourcenar's novel whose main character is a physician, Zeno (the title of the novel was translated into english as The Abyss or, alternatively, Zeno of Bruges). The paper begins with a brief introduction to the plot of L'Euvre au Noir. Then, given the amplitude of the topic, its scope is restricted to examine two issues: Zeno's medical training and his everyday professional life in Bruges.

\section{Résumé}

Partant du souci d'étudier la présence et l'image de l'histoire et de la société dans la littérature, cet article prétend analyser la représentation de la médecine du XVI ${ }^{\mathrm{e}}$ siècle dans L'Euvre au Noir (1968), roman de Marguerite Yourcenar dont le protagoniste est un médecin, Zénon. Après quelques réflexions sur les rapports entre la littérature et l'histoire, ainsi qu'une exposition très concise de l'intrigue de L'Euvre au Noir, nous nous limitons à examiner deux aspects de ce vaste sujet: d'abord et brièvement la formation médicale de Zénon, puis son quotidien (mode de vie et activité professionnelle) à Bruges.
Key words: Literature and History; Literature and Medicine; Sixteenth century; Yourcenar (Marguerite); L'CEuvre au Noir.

Mots-clés: Littérature et Histoire; Littérature et médecine; XVIe siècle; Yourcenar (Marguerite); L'CEuvre au Noir. 